\title{
Taomo Zhou, Migration in the Time of Revolution: China, Indonesia, and the Cold
}

War. Ithaca, NY: Cornell University Press, 2019, xvi + 318 pp. ISBN: 9781501739934 , price: USD 43.95 (hardcover).

This is a remarkable book. In an innovative way, Taomo Zhou analyzes the social, cultural, and political movements and activities of Chinese Indonesians in Indonesia between $195^{\circ}$ and 1970, and relates these to the changing nature of the diplomatic relationship between the People's Republic of China (PRC) and the Republic of Indonesia. Combining a historical analysis of both provides original insights into the social, cultural, and political activities of Chinese-Indonesians, the nature of the way the PRC positioned itself on the international stage, and the perceptions of the civic life of the ethnic Chinese by other Indonesians as well as politicians, military officers, and the police.

Based on her research on archival sources that were permitted within China for a relatively short period of time, Zhou puts the idea to rest that the assassination of six Indonesian generals on September 30, 1965 (Gerakan 30 September, or $\mathrm{G}_{3} \mathrm{OS}$ ) had been orchestrated by the PRC as part of a coup in order to establish a Communist regime in Indonesia. Even though Chinese leaders were aware that there were some plans for an uprising, they were not involved. They did not send weapons to support the uprising or provide any other type of support. Zhou's archival findings refute years of relentless anti-Communist propaganda by the Soeharto dictatorship, which had presented Chinese involvement as an indisputable fact.

In the early 195os, Indonesia was one of the first countries to recognize the PRC. To maintain cordial bilateral relations, the PRC subsequently ceased all forms of political involvement within Indonesia. It disbanded all branches of the Chinese Communist Party within Indonesia (and worldwide) in $195^{2}$ and discontinued its contact with numerous social, cultural, and political ChineseIndonesian associations. The fact that both Indonesia and the PRC (and, to make the situation even more complex, the Republic of China based in Taipei, Taiwan) claimed the ethnic Chinese as its citizens still caused considerable tension. In 1955, with the signing of the Sino-Indonesian Dual Nationality Treaty, the PRC ceased to do so (this treaty only became effective in 1960). In other words, to bolster a close political relationship with the Republic of Indonesia, the PRC ceased all political, social, and cultural activities within Indonesia. The PRC hoped to build an international alliance of recently decolonized countries to counter the worldwide influence of the United States and the Soviet Union. At the same time, the Taiwan-based Republic of China (ROC) continued its attempts to influence Chinese Indonesians through personal contacts, by infilt- 
rating ethnic Chinese organizations, and by strengthening ties with right-wing forces within Indonesia.

During the 1950s, the ethnic Chinese in Indonesia showed unprecedented levels of activity by launching civic campaigns, either in favor of the PRC or the nationalist regime in Taiwan, but also through social and cultural organizations. The former faction was more numerous, active, and outspoken. Despite the rivalry between both, most Indonesians were convinced that all this activity indicated unprecedented interference by the PRC. Most Indonesians were unaware of factional divisions among the ethnic Chinese; they continued to see this group as homogenous and viewed it with increasing suspicion-either because of its perceived economic dominance, or because of its links to Communist China. The Indonesian police and military as well as many politicians were deeply concerned about the growing influence of Communism in Indonesia, which, according to them, was evidence of political infiltration by the PRC. Hostility towards both Communism and the PRC increased during the 1950s. In 1959, Chinese Indonesians were no longer allowed to operate businesses and shops in the countryside in order to diminish their importance in the Indonesian economy and stimulate entrepreneurial activity among other Indonesians. Paradoxically, one additional motivation for this decision was Taipei's support for several regional rebellions.

In the early 196os, Sukarno's political orientation became increasingly left leaning, which motivated him to seek closer ties with the PRC. The severe economic problems Indonesia experienced at that time probably played a role as well. At the same time, the PRC aimed to establish close strategic alliances with Indonesia and various other formerly colonized nations on the basis of their shared past of anticolonial struggle and a desire to remain independent of the United States of America and the Soviet Union as the Cold War intensified. It was mainly interested in strengthening its international position, not in meddling in Indonesia's affairs. At the same time, the Indonesian military became increasingly concerned about the political strength of the Indonesian Communist Party (PKI), which they thought was related to the increasing influence of the PrC. They associated Chinese Indonesians with China's communist regime, which inspired the paradoxical idea that a small, wealthy Chinese elite controlled large parts of the Indonesian economy as ruthless and selfish capitalists but also supported China's communist regime. In 1967, after Soeharto became president, diplomatic relations with the PRC were suspended.

As Zhou illustrates with her meticulous research, the general perception of the PRC meddling in Indonesian affairs is unfounded; the high level of civic activity among Chinese Indonesians was motivated by internal conflicts, of which those between factions that either supported the PRC or the ROC were 
the most important. By combining analyses of the civic activities of Chinese Indonesians and the international pursuits of the PRC, she is able to draw several novel and compelling conclusions. Zhou's combined interpretation of the civic life among Chinese Indonesians and the political activities of the PRC in the global world is compelling and convincing. It will undoubtedly stimulate further scholarship on the civic life of the so-called overseas Chinese.

\author{
Hans Pols \\ University of Sydney, Sydney, Australia \\ hans.pols@sydney.edu.au
}

